for Marlow, who remained editor until 1946. But above all, they increased in quality until to-day they stand unrivalled in their own field. Marlow worked his referees hard, and they responded.

By nature, Marlow was ever ready to do people or causes a good turn, and this led to his being much in request just perhaps upon the periphery of his normal avocations. He served the Royal Institution as secretary of the Visitors' Committee, and was a manager at the time of his death. His magnanimous but firm reaction to the abortive proposal of that body to revise its by-laws somewhat drastically was characteristic. He was prepared for change, where change was necessary, but not for ruthless pruning of those noble, rounded phrases of which we shall never see the like again. He delighted in them, and all for which they stood.

In recent years, Marlow took much interest in the Society for Visiting Scientists, and would often be found at its headquarters, lending a friendly hand with whatever was afoot. But in all this, the Faraday Society was Marlow, and Marlow was the Faraday Society; wholly impossible was it to think of one without the other. And that, alas, is what in practice we are obliged to do now. Nobody is irreplaceable, but Marlow's life-line had been approaching the asymptote of indispensability for a number of years, and with its end the margin of contact is seen to be exceptionally narrow

ERIO K. RIDEAL

F. I. G. RAWLINS

\section{Prof. Selig Hecht}

THE death of Prof. Selig Hecht in New York on September 18, 1947, at the age of fifty-five, deprives the physiology of vision of one of its most outstanding workers. Hecht was born in Austria and was brought to the United States as a child. He studied and worked in the United States, in England, Germany and Italy. After a broad biological training, he devoted his life to the study of the mechanisms of vision, considered as a branch of general physiology. He became professor of biophysies at Columbia University and made his laboratory an international centre of visual research.

Hecht's main work was concerned with the investigation of the many visual functions in man, such as dark-adaptation, intensity discrimination, acuity and colour vision. He had begun, however, by studying the reaction to light of simple organisms, such as the clam Mya arenaria, and he carried out some remarkable experiments on the vision of insects. $\mathrm{H}_{\Theta}$ also worked on the photochemistry of visual purple. All these researches were inter-connected comparative studies trying to reach the principles of visual response. Hecht's method was quantitative and his experimental standards exacting. The introduction to his lucidly written papers was often a concise but critical synthesis of a mass of literature on the subject, including the early classical work, of which he had an exhaustive knowledge. His aim, he said, was not to add to, but rather to subtract from, the literature on vision.

The leading idea of Hecht's research was that the very first reactions which take race between light and the photo-receptors are bound to determine to a large extent the characteristics of the visual response. $\mathrm{He}$ therefore concentrated his attention on these reactions, because they were easier to study than more central processes, especially those in the brain.
One result of his work was to establish beyond doubt the duplex nature of the mechanisms of the human retina, corresponding to the division of its photoreceptors into rods and cones. He clarified the relation between the rod visibility curve and the absorption of visual purple, and he devoted much attention to the photo-chemistry and kinetics of the reactions initiated by light in the receptors, intro. ducing the notion of the 'stationary state' of excitation.

Just before the War, Hecht took up with characteristic thoroughness the problem of the minimum energy necessary for vision. He found that a man can see a source of light which delivers to his retina only six quanta or so, absorbed by the visual purple of the rods. Stimuli consisting of such small quantities of light have unique properties; for example, they undergo from one trial to the next uncontrollable variations, which are related to the uncertainty of seeing observed in the measurements.

Hecht worked strenuously on visual research for the American Forces during the War. As he was preparing to return to the study of quantum prob. lems, he died suddenly of a coronary thrombosis.

A painter and a man of discriminating taste, Hecht had many interests. A well-done piece of scientific work would fill him with delight. It was both as a scientific man and as an artist that, for example, he admired Schultze's pioneer work and his drawings of the retina. He was a brilliant lecturer and expositor -he wrote a book entitled "Explaining the Atom". The lack of synthesis discermible in present-day knowledge and teaching perturbed him, and he took an active interest in all the human implications of science. $\mathrm{H} \theta$ dealt with persons and ideas on the basis of their intrinsic worth and was always ready to give genuine help, so that he won the affection of all those working with him. Selig Hecht will be moumed by many friends and colleagues throughout the world, and his death is a great loss to science.

\section{H. Prrenne}

\section{Prof. M. C. Potter}

Prof. N. S. Alexander, Physics Department, Raffles College, Singapore, writes : An interesting link with Victorian science ends with the death at the age of nearly ninety of Prof. M. C. Potter [see Nature, April 17, p. 590]. Some time ago, Prof. Potter presented me with a copy of "A Treatise on Hydrostatics and Hydrodynamics" written by his uncle, Dr. Richard Potter, formerly professor of natural philosophy in University College, London. Part 2 of this work was completed in 1880, the author being then eighty-one years of age, and was published by M. C. Potter in 1887. These two lives between them span nearly 150 years.

Richard Potter's book takes one back into the 'caloric' controversy, and his view's are sufficiently shown by the following quotations: $(a)$ referring among others to Rumford's experiments, "The whole three cases are mills for grinding atmospheric air under pressure with the production of heat from its condensation"; (b) "In Mr. Joule's experiments which were performed in air, the effect rising from its presence is entirely neglected, and the phenomena of heat being attributed to the mechanical force applied alone ... the conclusions drawn from them are erroneous" ; (c) "c/c' (the ratio of the principal specific heats of a gas) $=1$ nearly for small values of $\delta$ (the condensation), and the instantaneous change 
in specific heat of a gas is insensible for small rarefactions and condensations. After some time which has not yet been ascertained, the change in capacity for caloric is completed, and the temperature has changed considerably."

Prof. M. C. Potter had clearly been influenced by these views, and up to the time of his death was endeavouring to show that the usual statement of the First Law of Thermodynamics is incomplete. He had obtained some quite interesting results on electrical effects accompanying various chemical and mechanical changes, and believed that the neglect of these effects constituted a fatal objection to the experimental basis of the First Law. He frequently used to remark, "Joule will have to go". Perhaps it would not be too much to refer to Dr. Potter as the last of the calorists.

WE regret to announce the following deaths :

Prof. S. C. Brooks, professor of zoology in the University of California, Berkeley, known for his work on the biological effects of radiations and the permeability of cells, on April 25, aged fifty-nine.

Dr. H. W. Richmond, F.R.S., president during 1920-22 of the London Mathematical Society, on April 22, aged eighty-four.

\section{NEWS and VIEWS}

\section{Arch æology in the University of London: Dr. R. E.} Mortimer Wheeler

Archeologists will be pleased to learn that Dr. R. E. Mortimer Wheeler has accepted a chair in the University of London. He shares with Sir Cyril Fox the distinction of being one of the most stimulating of archæological exponents in Great Britain. Dr. Wheeler has had a distinguished career both in archæology and in the army. For a time he was director of the National Museum of Wales, and then he became head of the London Museum. It was during this London Museum period that Mrs. Wheeler died; to her splendid personality and experienced help he owed much both personally and archæologically ; as, for example, when he set about the founding of the Archæological Institute, which is housed in Regent's Park. A member of the Territorial Army, the War sent him to Africa with the 8th Army and Italy with the 5th, where he ended up as one of the small band of non-professional scldiers who achieved the rank of brigadier. Recently, he has been directorgeneral of archæology in India. He has been president of innumerable archæological bodies and has served on the Royal Commission on Historical Monuments. Dr. Wheeler has undertaken not a few archæological excavations, the most important, perhaps, having been that at Maiden Castle, and has published ex. tensively on various subjects. His book "Prehistoric and Roman Wales" is a standard work on early times in that country. He has also written on the ancient sites at Lydney and Verulamium. His influence will greatly strengthen the growing school of archæology in the University of London, and we may look forward to many interesting results from excavations undertaken by him.

\section{Institution of Metallurgists: Dr. A. D. Merriman}

Dr. Arthur D. Merriman has been appointed to the full-time post of registrar-secretary of the Institution of Metallurgists. Dr. Merriman's initial training was in physics, mathematics and chemistry, and he has had some twenty years experience in academic fields, including the post of principal of the County Technical School, Wallsend-on-Tyne, 1926-38. During the early part of the Second World War, he served with the Directorate of Scientific Research, Ministry of Supply, and was the senior member of a group of scientific men and engineers dealing with bomb disposal problems ; for his personal courage in emergency situations he was awarded the George Cross. From 1941 until 1944 he was scientific adviser to the Com-
mander-in-Chief, Middle East, and in 1944 was appointed to a special intelligence assignment in the U.S.S.R., followed by similar work in north-west Europe and Germany. Since then he has been a principal scientific officer (technical intelligence) at the Armaments Design Department, Ministry of Supply. Dr. Merriman succeeds Dr. Harold Moore, the Institution's first president, who has been serving as registrar, and Mr. K. Headlam-Morley, secretary of the Iron and Steel Institute, who has acted as secretary of the Institution. Office accommodation will continue to be provided for the Institution at 4 Grosvenor Gardens, London, S.W.1.

\section{British Council Science Department: Mr. E. Bolton King}

Mr. E. Bolton KING, formerly managing director of the Oxford Instrument Co. and during the War a member of the Ministry of Supply Rocket Team, has been appointed director of the Science Department of the British Council. Educated at Warwick School and Balliol College, Oxford, where he was a mathematical exhibitioner, he obtained first-class honours in Physics Finals. He was elected to a research studentship at Christ Church, Oxford, and carried out research at the Clarendon Laboratory, largely on photo-electricity. Later he formed the Oxford Instrument Co. Early in the War he joined the Ministry of Supply Rocket Team under Sir Alwyn Crow and was engaged on rocket development, with special emphasis on proximity fuses, investigation of the performance of British and enemy rocket weapons in the Mediterranean theatre and liaison with rocket development in the United States, where he was an assistant director of the British Commonwealth Scientific Office. At the end of the War he went to Germany in connexion with the British firings of the V.2 rocket and became superintendent of the Ministry of Supply Establishment, Cuxhaven ; since then he has been in the Directorate of Guided Weapons of the Ministry of Supply.

\section{Exhibition of the Development of Lighting}

A SPECIAL exhibition, "Darkness into Daylight", was opened at the Science Museum, London, on April 29 to illustrate the development of lighting from the earliest times to the present day. A historical section, in which the Victoria and Albert Museum has co-operated, shows vividly by means of examples and dioramas the growth of lighting until the lamps of Swan in 1878 and Edison in 1879 marked the 